\title{
Liquid Culture of Ampelomyces quisqualis, a Mycoparasite for Biological Control of Powdery Mildews
}

\author{
Yu-Huan $\mathrm{GU}^{*, * *}$
}

\begin{abstract}
Ampelomyces quisqualis produced pycnidia but not conidia on malt-yeast extract (MY) agar, while in MY broth the fungus formed both pycnidia and conidia in 7 days. Shaking the culture greatly increased the amount of conidia produced in MY broth. Among the vegetables tested, carrot broth was best for conidial formation under shaking conditions, followed by tomato broth and cucumber broth. The fungus failed to grow in potato broth. When $A$. quisqualis conidia produced in carrot broth were incubated together with Oidium euonymi-japonicae conidia on glass slides under moist conditions, parasitism of this mycoparasite on its powdery host was observed for the first time outside the host of the powdery mildew.
\end{abstract}

(Received March 2, 1998 ; Accepted June 23, 1998)

Key words : conidial formation, biological control, mycoparasite, Ampelomyces quisqualis, powdery mildew.

\section{INTRODUCTION}

Ampelomyces quisqualis Ces. is a mycoparasite capable of infecting both asexual and sexual structures of many powdery mildew species in nature. More than 60 years ago, Yarwood ${ }^{11)}$ reported partial control of red clover powdery mildew with this fungus. Due to its wide host range, the mycoparasite is a highly promising candidate for biological control ${ }^{2}$. It also has potential for integrated disease management because of its tolerance to a number of fungicides used in the control of powdery mildews ${ }^{10)}$. The use of mycoparasites in biolog. ical control requires mass production of infective propagules. A. quisqualis is a slow-growing fungus and production of large amount of spores is usually difficult to obtain. The successful development of a method for mass production of conidia by this fungus with inexpensive and readily available material is reported here.

\section{MATERIALS AND METHODS}

Microorganisms A. quisqualis was isolated from Podosphaera leucotricha (Ell. \& Ev.) Salm. on the leaf of Malus pumila Mill. ${ }^{3)}$, and cultured on M2 agar ${ }^{6}$ to produce inoculum. Conidia of Oidium enonymi-japonicae (Arc.) Sacc. from Euonymus japonicus Thunb. were used to test ability of mycoparasite conidia, produced with the method described in this report, to parasitize the powdery mildew host. All the microorganisms used were collected from Lanzhou, China.

Conditions for conidial formation To compare the difference, in ability to support conidial formation in medium, between solid and liquid states the malt-yeast extract (MY) broth (7.5\% malt extract and 0.1 yeast extract) and MY agar (MY broth plus 2\% agar) were used. Fifty $\mathrm{ml}$ of MY broth was placed in each $250 \mathrm{ml}$ flask before autoclaving, while $25 \mathrm{ml} \mathrm{MY}$ agar was added to each $9-\mathrm{cm}$ petri plate after autoclaving. To inoculate the medium, six pycnidia of A. quisqualis were added to each flask or evenly distributed on the surface of each plate. For determining the effect of shaking the culture on conidial formation, flasks were incubated on a shaker adjusted to the speed of $100 \mathrm{rpm}$. Mycelial growth and pycnidial formation were recorded after 2,4 , 6 and 7 days at $25^{\circ} \mathrm{C}$. The numbers of conidia were determined on the 7th day with a Pipetman microliter pipette (P-20, West Scientific, Oakland, California, USA) $)^{5}$.

For comparing the ability of different vegetable extracts to support conidial formation, $25 \mathrm{~g}$ of peeled potato, tomato, carrot or cucumber was chopped into small pieces and boiled for $10 \mathrm{~min}$ with $50 \mathrm{ml}$ distilled water in a $250 \mathrm{ml}$ flask. The supernatant was filtered through four layers of cheesecloth and the filtrate was adjusted to $50 \mathrm{ml}$ with distilled water. Flasks were inoculated as described and data were recorded after incubation at $25^{\circ} \mathrm{C}$ for 7 days on a shaker.

Parasitism of cultured conidia Powdery mildew conidia of $O$. euonymi-japonicae were sprayed on

\footnotetext{
* Department of Biology, Northwest Normal University, Lanzhou, China

** Present address: Department of Plant Pathology, Beaumont Agricultural Research Center, University of Hawaii at Manoa, Hilo, HI 96720, USA
} 
Table 1. Effect of culture conditions on mycelial growth and pycnidial formation by Ampelomyces quisqualis

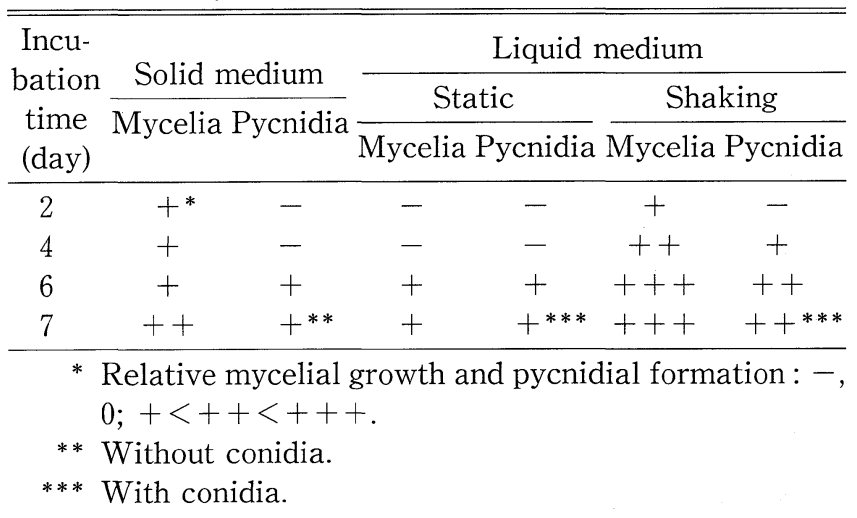

Table 2. Mycelial growth and conidial production of A. quisqualis in different vegetable broth under shaking conditions

\begin{tabular}{lcc}
\hline \hline Medium & $\begin{array}{c}\text { Mycelial weight } \\
(\mathrm{g} / 50 \mathrm{ml})\end{array}$ & $\begin{array}{c}\text { Conidial concentration } \\
(\mathrm{No} . / \mathrm{ml})\end{array}$ \\
\hline Carrot broth & $2.7 \mathrm{~A}^{*}$ & $2.4 \times 10^{7} \mathrm{~A}$ \\
Tomato broth & $2.6 \mathrm{~A}$ & $6.0 \times 10^{6} \mathrm{~B}$ \\
Cucumber broth & $0.1 \mathrm{~B}$ & $3.2 \times 10^{5} \mathrm{C}$ \\
Potato broth & 0 & 0 \\
\hline
\end{tabular}

* Data followed by the same letter in each column are not significantly different $(p=0.01)$ according to Duncan's multiple range test.

the glass slides by blowing air using an atomizer bulb4). Fifty $\mu 1$ conidial suspension of $A$. quisqualis obtained from carrot broth and washed twice with sterile distilled water by centrifugation ${ }^{8)}$ was then added onto each glass slide. The glass slide was placed on a V-shaped glass rod in a petri plate containing $10 \mathrm{ml}$ of sterile distilled water ${ }^{3)}$. Plates were sealed with parafilm and incubated at $25^{\circ} \mathrm{C}$. The interaction between powdery mildew host and the mycoparasite on the slides were observed once every $6 \mathrm{hr}$ for 3 days.

Data analysis Three replicates were used and each experiment was repeated at least once. Data were analyzed with Duncan's multiple range test.

\section{RESULTS}

Mycelial growth of $A$. quisqualis was detectable on the 2nd day on MY agar, but on the 6th day in MY broth without shaking (Table 1). The fungus formed pycnidia after 6 days under both conditions. However, pycnidia produced on MY agar did not contain conidia after 7 days, while those produced in MY broth released $1.3 \times$ $10^{4}$ conidia per $\mathrm{ml}$ of the medium. Shaking the culture greatly improved mycelial growth and pycnidial formation of $A$. quisqualis in MY broth (Table 1). The number of conidia released from pycnidia reached as high as $1.2 \times 10^{7}$ per $\mathrm{ml}$ of the medium after 7 days. Liquid and
Table 3. Effect of concentration of carrot broth on mycelial growth and conidial production of Ampelomyces quisqualis under shaking conditions

\begin{tabular}{|c|c|c|}
\hline $\begin{array}{l}\text { Concentration of } \\
\text { carrot broth }(\%)^{*}\end{array}$ & $\begin{array}{l}\text { Mycelial weight } \\
(\mathrm{g} / 50 \mathrm{ml})\end{array}$ & $\begin{array}{c}\text { Conidial concentration } \\
(\mathrm{No} . / \mathrm{ml})\end{array}$ \\
\hline 100 & $2.4 \mathrm{~A}^{* *}$ & $5.6 \times 10^{6} \mathrm{~B}$ \\
\hline 50 & $2.2 \mathrm{~A}$ & $1.9 \times 10^{7} \mathrm{~A}$ \\
\hline 25 & $1.3 \mathrm{~B}$ & $1.5 \times 10^{7} \mathrm{~A}$ \\
\hline 12 & $0.6 \mathrm{C}$ & $6.0 \times 10^{6} \mathrm{~B}$ \\
\hline 6 & $0.6 \mathrm{C}$ & $5.2 \times 10^{6} \mathrm{~B}$ \\
\hline 3 & $0.2 \mathrm{D}$ & $2.8 \times 10^{6} \mathrm{~B}$ \\
\hline
\end{tabular}

* Stock broth (100\%), prepared by boiling $50 \mathrm{~g}$ of chopped carrot in $50 \mathrm{ml}$ of distilled water, was adjusted with distilled water to make various concentrations of broth.

** Data followed by the same letter in each column are not significantly different $(p=0.01)$ according to Duncan's multiple range test.

shaking conditions were, therefore, selected for subsequent tests to find an inexpensive material for mass production of pycnidium by this fungus.

Among the materials tested, carrot broth was best for conidial formation of $A$. quisqualis, followed by tomato broth and cucumber broth (Table 2). The fungus grew poorly in cucumber broth and failed to grow in potato broth. Although $100 \%$ of carrot broth increased mycelial growth, it greatly decreased the amount of conidia produced (Table 3). Decreasing the stock carrot broth two fold did not significantly affected conidial formation, but substantially reduced the mycelial growth. Further dilution of carrot broth was not good for both conidial formation and mycelial growth.

On the glass slides, $A$. quisqualis conidia around $O$. euonymi-japonicae germinated at higher rate and produced longer germ tube than those away from the powdery mildew conidia. After $24 \mathrm{hr}$, germ tubes near the host conidia were about 5-10 times longer than the conidia, while those far from the host conidia were only about $0.5-5$ times longer. Germ tubes tend to grow toward host conidia. After entering the host, the mycoparasite may emerge from the same or opposite side of the host conidium (Plate I-A, B). Those germ tubes penetrating through host conidia grew 10-20 times longer than those not in contact with the host conidia in 60 hr after inoculation (Plate I-C). The host conidia penetrated by the mycoparasite showed rougher surface than those not be penetrated in $72 \mathrm{hr}$ after inoculation (Plate I-D).

\section{DISCUSSION}

The method presented in this report for production of A. quisqualis conidia has the advantages of being simple and inexpensive. The concentration of conidia produced in culture medium with this method was about 2.5 times higher than that reported by Sztejnberg et $a l^{9)}$ using 


\section{Plate I}

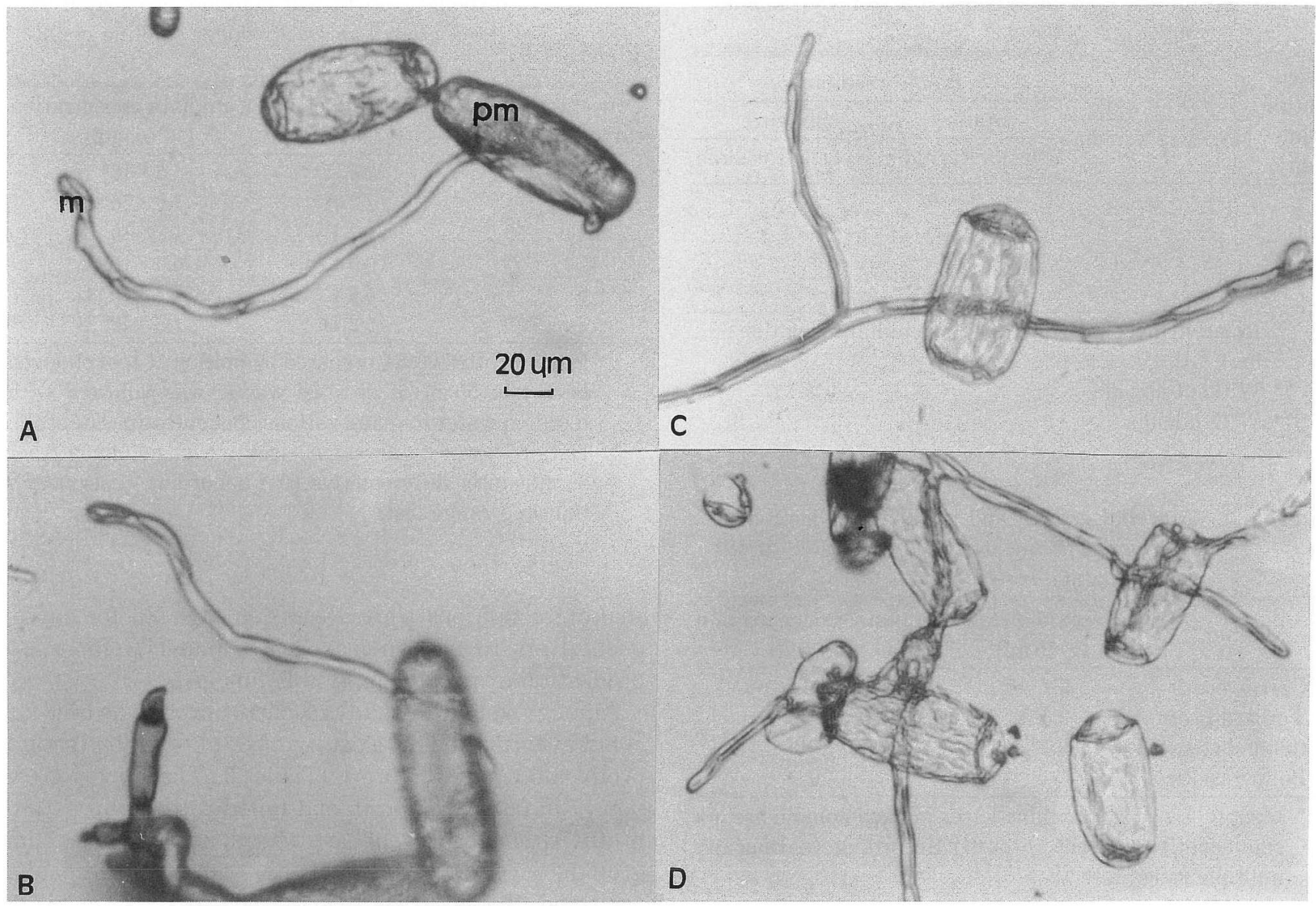

Plate I Parasitism of Ampelomyces quisqualis on powdery mildew Oidium euonymi-japonicae conidia.

(A) Emergence of the mycoparasite from the same side of the host conidium in $36 \mathrm{hr}$ after inoculation (m, mycoparasite conidium ; pm, powdery mildew conidium).

(B) Emergence of the mycoparasite from the opposite side of the host conidium in 36 hr after inoculation.

(C) Penetration of the host conidium by the mycoparasite in $60 \mathrm{hr}$ after inoculation.

(D) Parasitism of the mycoparasite on the host conidia in $72 \mathrm{hr}$ after inoculation.

potato broth under shaking conditions. Moreover, these conidia were capable of infecting powdery mildew conidia. It is, therefore, suitable for mass production of infective propagules of this mycoparasite for biological control.

Sztejnberg et $\left.a{ }^{9}{ }^{9}\right)$ reported growth and conidial formation by $A$. quisqualis in potato broth and potato dextrose broth. However, the fungus failed to grows in potato broth in this study and Chen \& Yang ${ }^{1)}$ was not able to culture it in potato dextrose broth. The difference in geographic origin might account for such discrepancy. Moreover, the Israeli isolate used by Sztejnberg et al. ${ }^{9)}$ was isolated from Oidium sp. parasitizing Catha edulis, while the Chinese isolate used in this study was obtained from $P$. leucotricha on $M$. pumila.

Since powdery mildews are obligate parasites, all the previous studies on interaction of mycoparasite and its powdery mildew host were carried out on the host of the powdery mildew ${ }^{2,7,10)}$. By incubating $A$. quisqualis conidia together with powdery mildew conidia on glass slides under moist conditions, parasitism of the mycoparasite was shown for the first time outside the host. This may be useful for studying factors affecting parasitism of $A$. quisqualis on its powdery mildew hosts.

I thank Dr. W.H. Ko of the University of Hawaii for critical review of the manuscript.

\section{Literature cited}

1. Chen, D. and Yang, Z. (1990). Studies on hyperparasite of powdery mildew. J. Nanjing Agric. Univ. 13(2) : 64-68.

2. Falk, S.P., Gadoury, D.M., Cortesi, P., Pearson, R.C. and Seem, R.C. (1995). Parasitism of Uncinula necator cleistothecia by the mycoparasite Ampelomyces quisqualis. Phytopathology 124 : 285-295.

3. Gu, Y.H. and Ko, W.H. (1997). Water agarose medium for studying factors affecting germination of conidia of Ampelomyces quisqualis. Mycol. Res. 101(4) : 422-424.

4. Gu, Y.H. and Zhang, X.L. (1993). Volatile germination 
stimulators of conidia of powdery mildews. Mycologia 85 : 203-205.

5. Ko, W.H., Chase, L.L. and Kunimoto, R.K. (1973). A microsyringe method for determine concentration of fungal propagules. Phytopathology 65: 1206-1207.

6. Mhaskar, D.N. (1974). Mycoparasite-Ampelomyces in artificial culture I. Morphology and cultural behaviour. Mycopathol. Mycol. Appl. 52 : 55-64.

7. Sundheim, L. (1982). Effects of four fungi on conidial germination of the hyperparasite Ampelomyces quisqualis. Acta Agric. Scand. 32 : 341-347.

8. Sundheim, L. (1982). Control of cucumber powdery mildew by the hyperparasite Ampelomyces quisqualis and fungicides. Plant Pathol. 31 : 209-214.

9. Sztejnberg, A., Galper, S. and Lisker, N. (1990). Conditional for pycnidial production and spore formation by Ampelomyces quisqualis. Can. J. Microbiol. 36 : 193-198.

10. Sztejnberg, A., Galper, S., Mazar, S. and Lisker, N. (1989). Ampelomyces quisqualis for biological and integrate control of powdery mildews in Israel. J. Phyto- pathol. $124: 285-295$.

11. Yarwood, C.E. (1932). Ampelomyces quisqualis on clover mildew. Phytopathology $22: 31$.

\section{和 文 摘 要}

Yu-Huan Gu：うどんこ病の生物防除に利用できる菌間寄生 菌, Ampelomyces quisqualis の液体培養

Ampelomyces quisqualis は麦芽, 酵母エキス寒天培地上では 柄子殼のみを形成し, 分生子を形成しなかったが, 麦芽, 酵母工 キス液体培地で培養すると 7 日間で柄子凯および分生子を形成 した。振とう培養によって分生子形成量は増大した。各種植物の 煎汁で液体培地を調製して本菌の分生子形成量に及ぼす影響を 調べたところ,ニンジン,トマト,キュウリの順に形成量を増大さ せたが, ジャガイモ培地中では菌の成育が見られなかった。二ン ジン液体培地で形成させた本菌の分生子と Oidium euonymijaponicae の分生子とを湿室内のスライドガラス上で培養した ところ, 前者が後者の表面に寄生している様相が確認された。 